\title{
WHAT IS VALUABLE IN THE ACADEME: CORPUS-BASED ANALYSIS
}

\author{
Albina Vodyanitskaya \\ Moscow City Teacher Training University, Russian Federation \\ Vera Yaremenko \\ National Research University MIET, Russian Federation
}

\begin{abstract}
The paper focuses on the corpus-based analysis of academic discourse values. The research aim is to reveal how teachers transmit academic discourse values through their everyday interactions with students (during lectures, seminars) and to reveal, which values are relevant for the students (based on the analysis of their essays, research papers and some such). The research relies on corpus-based approach and primary methods used are a semantic analysis and a context analysis as well as definition analysis of evaluative means. The research results have revealed that various values play important role in academic interactions and shape the image of the academe - on the local as well as on the global scale. The study of the contexts containing the word valuable in British National Corpus (Davis, 2008-), British Academic Spoken English (Nesi \& Thompson, 2000-), British Academic Written English (Nesi, 2008-), Corpus of Russian Student Texts (Rakhilina, Zevakhina, \& Dzhakupova, 2013-) and Michigan Corpus of Academic Spoken English (2002-) has revealed that the values of academic discourse can be subdivided into six domains: emotional, cognitive, educational, research-related, academic life-related, topic- / area-related. The further applicability of research findings manifests itself in various avenues of research: linguistics (evaluative means), axiology (cross-disciplinary study of values), teaching practices (academic discourse genres) and others.
\end{abstract}

Keywords: academic corpora, academic discourse, axiology, evaluation, values.

\section{Introduction}

The corpus-based research of the values in academic discourse is a part of a wider research on evaluative means in the academic discourse and their interrelation with the axiology and values of the academe. It is believed (Suleimanova, Yaremenko, \& Vodyanitskaya, 2018; Vodyanitskaya, 2018) that the latter are strongly interrelated with evaluation. The study of academic values in English and Russian academic corpora is aimed at revealing the values of the academe across disciplines (for the corpora analyzed in this research cover various branches of the academic curriculum) and on the global scale, for the values of English and Russian academic discourse have been analyzed in this research. 
The importance of the topic manifests itself in the scholarly attention to the ethics of academic discourse as well as to research ethics. Education researchers dwell on the ethics of argumentation in the framework of academic discourse (Robinson, 2009). Moreover, principles of success in research environment are interconnected with ethic values of academic discourse (Collister \& Deliyannides, 2019). Honesty, trust, fairness, respect, responsibility and courage are regarded as symbols and proof of academic integrity (Fishman, 2014). Nowadays, when the universities state their mission, they rely heavily on the unwritten and unspoken, yet existing values of academic discourse. Therefore, the analysis of the way the academic values are perceived and transmitted is a relevant issue.

To reveal the academic values, we relied heavily on corpus-based approach and analyzed the texts from academic corpora - we searched for the contexts in which the words valuable (for English corpora) and tsenniy (for the Russian corpus) were used and analyzed, which realia of academic discourse they characterize. Teachers transmit academic values to their students because they are relevant in terms of research ethics, as well as in terms of empowering students for their future professions, when their ethical behaviour will play a crucial role for their career. At the same time, the corpus of students' written texts was analyzed to reveal which values are perceived by the students as relevant in their research practice.

Therefore, the research has revealed that the values of academic discourse belong to various domains: emotional, cognitive, educational, research-related, academic life-related, topic- / area-related.

\section{The relevance of research}

As far as values are interconnected with evaluative means (Ivin, 2006), the first step towards analyzing them and extracting them from the written text is through the analysis of evaluation. J. Channell aptly puts it, the "analysis of evaluation can be removed from the chancy and unreliable business of linguistic intuitions and based on systematic observation of naturally occurring data" (Channell, 2002, p.39). The author claims that when analyzing evaluative linguistic means, it is the corpus-based approach "that produces a sound description of this aspect of language", moreover, "it allows observations which go beyond what intuitions can achieve, in revealing evaluative functions which intuitions fail to pick up" (Channell, 2002, p.39). As far as evaluation is interconnected with the system of values it seems relevant to apply this corpusbased approach to researching values of the academe.

D.S. Giannoni's research focuses on the mapping of the values of academic discourse based on the analysis of evaluative lexemes which allow to group the 
values into "four categories linked to different axiological variables: size, novelty, goodness and relevance” (Giannoni, 2010, p.212). When it comes to evaluation, the figure of the observer is extremely important, for in some cases, a lot depends on the 'eyes of the beholder'. D.S. Giannoni claims that "size and novelty are the two more observer-independent values, because their perception is less a matter of personal opinion than the evaluation of goodness and relevance” (Giannoni, 2010, p.213). In this study, the focus is - specifically and intentionally - on the contexts containing the adjective valuable in English academic spoken and written corpora, as well as on the entries with the word ценный (valuable) in Corpus of Russian Student Texts. Therefore, the emphasis is on the realia that are valuable for academic discourse participants. The emotional, cognitive, educational, topic-related, research- and academic liferelated domains within which various values of the academe exist, is one more attempt to group various values that constitute the core of this specific type of discourse.

\section{Methodology: research process}

The research process involved several stages.

First and foremost, the relevant corpora were selected. We focused on academic corpora (both written and spoken).

Secondly, we selected the contexts containing the word valuable in English corpora and the word tsenniy (valuable) in Russian corpora.

Further on, we analyzed the objects, or realia of academic life, that were characterized as valuable, and focused our attention on the contexts, to grasp the essence of what is rated as valuable in each context.

To reveal the values of academic discourse, we relied on semantic analysis, discourse analysis and on context analysis, based on corpus-based approach, when the amount of texts under analysis provides for relevant conclusions (both in terms of quality and in terms of quantity).

The last stage of the research involved grouping the values of the academic discourse based on dominant characteristics of the realia rated as valuable as well as based on contexts, in which they appeared in the texts.

\section{Methodology: opting for corpora}

To analyze values of academic discourse, we have turned to various corpora (Michigan Corpus of Academic Spoken English, British National Corpus, British Academic Spoken English, British Academic Written English and of Russian Student Texts). 
The first stage of the research focuses on the data collecting. Initially, we find out, in which contexts the adjectives valuable and tsenniy (valuable) occur in written and spoken academic corpora. Spoken academic contexts are overwhelming in their manifestations: lectures, colloquiums, teacher's conferences, scientific conferences, seminars. The unique nature of the spoken corpora manifests itself in the fact that the material for lectures, for example, is meant to be prepared (written) beforehand, and, in this respect, we deal with the written embodiment of academic discourse, at the same time, during a lecture a teacher may ask questions or start telling topic-related stories. To grasp the moment of improvisation or interaction is extremely important, for this is the time when values are likely to be voiced. Therefore, the chance to search and browse corpora of spoken academic English is a unique one. Spoken corpora has already attracted scholars in terms of academic culture and lecturing styles (see, for example (Chia-Yen, 2012)).

Let's briefly dwell on the corpora that have been selected for the research:

British National Corpus (Davis, 2008-) offers search options that allow the researcher to select the body of texts needed. In the framework of this research, we have opted for written academic and spoken academic texts. Moreover, it is possible to choose, for example, an academic division (Humanities, Arts, Sociological science, et cetera) as well as the type of academic genre (essay, paragraph, thesis, letter) as well as academic event (lecture, colloquium, conference etc.). Thus, for example, the research has revealed that the word valuable is often met in the Teachers' conference focusing on the discussion of assessment procedures. The corpus provides such relevant information as: the date of the event (e.g. September 3, 1992), the number of participants (7) as well as the quantity of utterances pronounced (1966). Moreover, the status of the event is highlighted (educational and informational). This seemingly extra-linguistic data is extremely valuable for our research, for it helps define the context in which the value-related word appears.

Among various aspects that The British Academic Spoken English (Nesi \& Thompson, 2000-). The corpus facilitates, the most relevant and important for this research are: "the frequency and range of academic lexis, patterns of interaction, including turn-taking and topic selection, the representation of ideas and the expression of attitudes" (for other aspects see: BASE web-site). Each entry is provided with the relevant information on the title of the event (e.g., Introduction to the Laboratory), academic division (Life Sciences, for example), speech event (lecture, e.g.), academic department (Biological Sciences). There is evidence to suggest that this corpus is disciplineoriented, for it is very explicit about the academic divisions and subdivisions, 
which makes it relevant for cross-disciplinary analysis of the values of the academe.

The British Academic Written English Corpus (Nesi, 2008-). was collected as part of the project, An Investigation of Genres of Assessed Writing in British Higher Education'. As stated on the BAWE web-site, "the corpus is a record of proficient university-level student writing at the turn of the 21st century. It contains just under 3000 good-standard student assignments (6,506,995 words). Holdings are fairly evenly distributed across four broad disciplinary areas (Arts and Humanities, Social Sciences, Life Sciences and Physical Sciences) and across four levels of study (undergraduate and taught master's level). Thirty main disciplines are represented" (Nesi, 2008-). It is worth mentioning that the BAWE provides the users with the information about the genre (essay, critique, methodology recount etc.). The authors of the BASE as well as of BAWE pay a lot of attention to the description of extra-linguistic contexts. We argue that for a written corpus, it is extremely valuable to give a wider linguistic context, while for a spoken corpus the extra-linguistic one is of prime importance.

In this research, the data provided by The Corpus of Russian Student Texts (KPYT in Russian, or CoRST) (Rakhilina, Zevakhina, \& Dzhakupova, 2013-) have also been analyzed. The corpus is the collection of texts written by the students from various universities of Russia. The number of words of the corpus amounts to 2.6 million words. The CoRST is intended for analyzing language variability and linguistic changes, as well as the mistakes in the language use. The corpus is relevant for our research, for it contains student essays, reviews, reports, articles and other assignments that contain important information on what is valuable in the academe through the prism of contemporary students' perceptions. Importantly, the information about the degree the student is pursuing, as well as the year of study and the disciplinary area, accompanies every written text in the CoRST (for more information see (Rakhilina, Zevakhina, \& Dzhakupova, 2013-).

Last but not least, is The Michigan Corpus of Academic Spoken English (2002-) which offers a variety of search options that enhance any research horizons. What makes this corpus unique, is the opportunity to choose speaker attributes (age, gender, academic position, native speaker status, first language) and transcript attributes (speech event type, academic division, academic discipline, participant level, interactivity rating). With 152 transcripts, this ability to browse and search with the opportunity for such precise inquiry is impressive. The relevance of the corpus data for our research is evident, for one can create all the contexts imaginable for the word valuable, and analyze existing and non-existing contexts. So, for example, for the word valuable, initially, we 'created' the following context: speaker attributes: gender, age, 
native speaker status, first language - all, while academic position - junior graduate student. As for transcript attributes, we have opted for colloquium, Humanities and Arts, American Culture, junior graduate student, highly interactive. The search and browse result is zero matches and zero transcripts. These zero results are also extremely valuable for the research, for they show the extra-linguistic contextual limits of the evaluative valuable.

\section{Data collection: searching and ranking}

After having opted for the above mentioned corpora, we have focused on the contexts in which the words valuable and ценный (valuable) appear. Initially, the contexts were grouped according to thematic principle: the examples were grouped into two categories: relating to university life (academic interactions, institutional relationship etc.) and to the topic that is being discussed during the lecture, a seminar, or in an essay or another assignment.

Further on, the semantic analysis of 1300 contexts has revealed that within these two major groups there is a diversity of values and the division into just two types is very rough. Therefore, the contexts were grouped into six domains, where various values occur, they are: emotional, cognitive, educational, research, academic life-related and topic-related domains.

One might ask, on what grounds we differentiate between various domains, for, strictly speaking, every value is connected with the university life. We have to admit, that sometimes the margin between the contexts is very fragile. So, for example, when the teacher reveals for the students the relevance and importance of their teacher's actions (the teacher stays after classes to make sure the students understand the aim of the project and their role in it, for example), describes the teacher's attitude to work and to students, she speaks about the academic life, the interactions between the people involved into institutional relationship. What is more relevant and specific here, though, is the fact that she describes the teacher's actions and considers them valuable through the prism of her own emotions that she voices. Emotional domain, though describing academic life, for example, as illustrated in the examples below, is at the same time a manifestation of what the person feels about various aspects he or she considers valuable.

When grouping the contexts, we focus on the evaluative word and the object it defines. Where the corpus allows, wider contexts are being analyzed for a deeper understanding of what the speaker, or writer, means. We deliberately bring in a wider context so that the whole picture was vivid.

The final stage of the research is devoted to interpreting the contexts within each domain. As far as values and evaluations are interconnected, the interpretation of the data is important and valuable step for a deeper 
understanding of nature and ontology of the values in the academe as well as evaluations.

\section{Corpus-related Research}

Various aspects of BNC have been studied by the scientists across the globe. Thus, for example, (Lijffij \& Nevalainen, 2017) offer a simple model for recognizing core genres in the BNC. The authors "selected only the subgenres that are prototypical representatives of these genres: demographically sampled conversations, prose fiction, broadsheet newspaper texts and academic prose" (Lijffij \& Nevalainen, 2017). Moreover, "focus on structural properties of texts, analysing word and sentence length, type/token ratios and relations between part-of-speech categories. Such basic text analytic measures can be observed and analysed in any set of written texts that come with the required markup" (Lijffij \& Nevalainen, 2017). Mostly, the BNC corpus has been studied in the sphere of genres (Nesi \& Gardner, 2018; Hsu, 2018).

Extralinguistic parameters such as laughter in academic talk have been studied in (Carey, 2014); MICASE is mentioned in (Bamford \& Bondi, 2005): "corpora of spoken academic discourse have enabled us to put our fingers on exactly those features which make academic so much more like other spoken discourse rather than like written discourse with respect to previous studies. For example, like its conversational counterpart, spoken academic discourse avoids overt confrontation and prefers consensus building”.

\section{Findings and results}

Various contexts containing axiology-related words have been analyzed. The contexts show that values of academic discourse are diverse and multilayered: they are existential, social, ethical, esthetical, discipline-, academic life-, knowledge-related. Values of the academe (British, American and Russian) can be grouped into six domains: emotional, cognitive, educational, research, academic life-related and topic-related.

\section{Values within the Emotional Domain}

As it was mentioned above, the emotional domain deals mostly with the feelings of the speaker or writer. Let's turn to the following example from MICASE:

no one had told me how to insist that my creative work be, evaluated differently than your scholarly work is. these all of the things that I didn't know when I was coming through twenty-five years ago. and these are all the things that you know now. you see these are the things that Rackham takes out time, to make sure you have this information I can't tell you how valuable that is. and I 
can't um, I can't tell you, what it means, for minds across disciplines to be able to meet. you're not gonna have that anywhere else. than in the academy. minds across disciplines wide expanses of disciplines. and it makes you a richer person it makes you a fuller person. it makes you a warmer person it makes you a better person... (Michigan Corpus of Academic Spoken English, 2002).

In this, mostly interactive, Career Planning and Placement Workshop, the speaker (senior faculty, female, 31-50 years old) explains to her students the value of having the opportunity to meet their teacher after classes and to discuss relevant issues, concerning the curriculum and the discipline. The teacher gives an example from her own life, when she faced various challenges connected to her academic life, with uncertainty being one of them. By contrast, her students have the opportunity to challenge the uncertainty. Student uncertainty has been in the focus of academic attention, see, e.g., (Jordan, 2015; Hartner-Tiefenthaler Roetzer, Bottaro \& Peschl, 2018), for it inhibits the incentive to learn and to study. The teacher emphasizes the role of her colleague by using the emphatic $I$ can't tell you how two times. Moreover, she turns the students' attention to the fact that that is valuable from the institutional and academic point of view. Moreover, she attributes a great role to the interaction between the minds across disciplines. An outcome of such interactions is the transformation of students' personality - psychologically (a fuller person), emotionally (a warmer person), spiritually (a richer person) and socially (a better person). In this vivid example, we move from purely emotional domain into existential categories. It is worth mentioning, that this Workshop was initiated by the students who wanted to know what it means to be a faculty member. It seems that through storytelling, through personal examples, the teachers offer their students the value landscape of the academic discourse, for such actions like staying after classes, or meeting academic minds might be perceived by the students as something that is presupposed by the very fact that they are students, and there is nothing special in it. The teacher has unveiled for the students the value of their everyday experience in the academe. Being once voiced, these values are meant to stay with them, perceived by them and appreciated by them. The educational as well as professional outcomes of such talks are invaluable.

\section{Values within the Cognitive Domain}

When the word valuable is used by a teacher to refer to the results of students' cognitive operations, the contexts illustrating it are grouped into the cognitive domain. The following example shows that the teacher (junior faculty, female, 24-30 years old) describes the student's comment as valuable:

... okay I'm gonna carry that comment on because I think it's a very valuable comment here. um, the question is it fair, to jump on one show and to say that this show should embody everything, that's needed for, a positive portrayal of a group? um and I'm gonna recall, your article that you had to read 
by Graves, just some thoughts from the Graves article, to try to frame your thoughts about the Cosby Show... the first thought, is... Graves makes a distinction... (Michigan Corpus of Academic Spoken English, 2002-).

There are also contexts, when the value of experience and expertise is highlighted - in all the cases analyzed, the author of the evaluative judgement either claims that experience is valuable, or calls the audience for undertaking a cognitive journey to decide what is worth learning, and what is not:

... be it's not exactly a bad thing to, learn, new stuff. yeah, that's true, um, definitely. um <PAUSE:04> but how do you know what kind of, what kind of stuff that you, that you wanna learn...? ho- I mean how do you know what kind of stuff is, is more important or more valuable? yeah. you have to experience it all, and then you get to, to decide after that. I mean that's definitely, that's definitely, that's definitely um, that's definitely, true, to s- I mean with- within some boundaries right though. ...(Michigan Corpus of Academic Spoken English, 2002-).

In this example, the speaker (junior graduate, female, aged 24-30) emphasizes that to understand what is valuable, what is worth studying, one should receive a lot of experience before one decides for him or herself what deserves studying. The speaker backs up her opinion by repeating the evaluative adverb definitely four times. In this context, the value of experience and expertise is highlighted.

If we compare these two examples from the cognitive domain, we will see that when the teacher calls the student's comment valuable, this comment is the result of the students' cognitive work. The comment corresponds to the teacher's ideas and to the main topic of the lecture, and the teacher has the authority to name the comment valuable. In the second example, the junior graduate is ruminating excessively on the cognitive processes of deciding on the value of stuff one is supposed to learn. The speaker does not evaluate anybody's cognitive abilities, but calls for the evaluation and cognitive action. In this respect, these two examples are different in terms of the nature of evaluation, but they are equal in terms of the values they emphasize.

The examples from The Corpus of Russian Student Texts have also shown that students tend to attribute a great importance to experience. It is worth mentioning, that mostly junior students state the value of experience in their essays: 


\section{Table 1 The value of experience stated (cognitive domain)}

\begin{tabular}{|c|c|}
\hline Transliterated version of the Russian text & Translation \\
\hline $\begin{array}{l}\text { My cherpaem znaniya iz knig, fil'mov, ot } \\
\text { svoih znakomyh i, razumeetsya, uchimsya na } \\
\text { sobstvennyh oshibkah, priobretaya, takim } \\
\text { obrazom, tsenniy opyt. No vstremlenii } \\
\text { poluchit' kak mozhno bol'she znanij za } \\
\text { maksimal'no korotkoe vremya lyudi } \\
\text { zabyvayut o tom, chto nedostatochno prosto } \\
\text { uznat' chto libo, vazhno 'eto esche i ponyat', } \\
\text { inache takie znaniya budut absolyutno } \\
\text { bespolezny na praktike (Rakhilina, } \\
\text { Zevakhina, \& Dzhakupova, 2013-). }\end{array}$ & $\begin{array}{l}\text { We learn from books, films and, definitely, } \\
\text { learn from our own mistakes, getting } \\
\text { through this valuable experience. At the } \\
\text { same time, in our pursuit of getting as much } \\
\text { as possible within a short period of time, we } \\
\text { forget that it is not enough just to learn } \\
\text { something. It is vital to understand the } \\
\text { essence of what we have learnt, otherwise, } \\
\text { such knowledge is useless and impractical } \\
\text { (translated by Albina Vodyanitskaya and } \\
\text { Vera Yaremenko). }\end{array}$ \\
\hline
\end{tabular}

The Table 1 shows that in this essay, written by a first-year student pursuing bachelor's degree in sociology, the value of the experience is emphasized. At the same time, the student highlights the importance of learning and understanding, otherwise, such knowledge proves useless. It seems that students across disciplines and cultures attribute a crucial role to experience and expertise. Interestingly, in CoRST mostly junior students emphasize the value of experience in their written assignments. We argue that this value is rooted in the fact that the students are at the very beginning of their university life and they wish to acquire as much practice as possible. It is worth mentioning that both in CoRST and in MICASE contexts students warn the readers or the audience against consumerism in learning: one is expected to be sophisticated when choosing what to learn. This wish to warn the potential reader proves the dialogic nature of academic discourse and can be traced back to M.M. Bakhtin's works on the polyphony of written texts (Bakhtin, 1986). Nowadays, the polyphony of academic discourse is studied in terms of the dialogue with the Other (Suleimanova, 2018). O.A. Suleimanova's research has revealed a multilayered figure of the Other in the academe. The author claims that polyphony is inherent in academic discourse and in the process of academic communication new hypotheses and theories are being crystallized and formed (Suleimanova, 2018, pp. 196-197).

\section{Values within the Academic Life-related Domain}

Academic interactions are based on various values, some of which are explicitly verbalized in Student behaviour code, while the others exist unvoiced. "Academic discourse, both written and spoken, is highly patterned, interactive and socially constrained" (Bamford \& Bondi, 2005, p. X). Let's have a look at the following example that demonstrates the way the teacher (Native speaker, 
American English senior faculty, female, aged 31-50) evaluates the feedback teachers get from students:

... frightening when you first start having students write back to you, you know that was one of the methods we learned as Lily Teaching Fellows, you know that you have them write back to you well how'd you think class went today. well what would you like to do more of? you know what would you like to do, it's very frightening. but, if you can just, kinda gird your courage, then you find it's a very valuable, you know exchange. (Michigan Corpus of Academic Spoken English, 2002-).

In this entry, the teacher is discussing a new trend in teaching: receiving students' feedback. The first impulse of evaluation is entwined with emotions: it is frightening, yet, when one girds his or her courage, one can find this exchange valuable and promising. Interestingly, the teacher emphasizes, that it's not the feedback that frightens her, but the fact that the students might offer some changes in the curriculum or in the discipline content. Institutionally, the role of feedback- and assessment-provider is attributed to teachers, "discourse is constitutive of the community and its identity and has to be learned by interaction between the expert and the novice member" (Bamford \& Bondi, 2005, p. XIII), so, this new experience requires braveness from the teacher. Nowadays, students' feedback is an emerging trend in teaching practice, and it is researched on the global scale (see, e.g.: Zenobya, Chan, Meadus, \& Chien, 2017; Masantiah, Pasiphol, \& Tangdhanakanond, 2018). At the same time, this is a brave new trend that requires certain approach and skills.

\section{Values within the Research Domain}

Doing a research is one of the most important aspects while studying at a university. Research domain focuses mainly on writing, for as K. Hyland aptly puts it, "writing is a socially situated process of making meanings through texts, so that becoming a competent writer is not just a linguistic or cognitive process but a sociocultural one, which requires learners to appropriate the meanings created in the contexts in which they operate" (Hyland, 2016, p.157).

Research is values-oriented for "members of a discourse community have developed conventionalized or standardized solutions both as writers and as readers to manage recurrent social tasks (both written and spoken) since texts respond to recurrent communicative needs. In academic discourse textual patterns typical of genres in various disciplines come to assume a particular social valency within the discourse community and apprentice readers and writers can ill afford to ignore them (Bamford \& Bondi, 2005, p. XI).

When doing a review of the conference topics, the first-year student majoring in Linguistics, comes to a conclusion: 
Vodyanitskaya \& Yaremenko, 2020. What is Valuable in the Academe: Corpus-Based Analysis

Table 2 Conference's value stated (research domain)

\begin{tabular}{|c|c|}
\hline Transliterated version of the Russian text & Translation \\
\hline $\begin{array}{l}\text { Konferenciya } \text { nosila metodologicheskij } \\
\text { harakter [...] Materialy konferencii } \\
\text { predstavlyayut soboj ochen' tsenniy } \\
\text { istochnik po osobennostyam i granicam } \\
\text { primeneniya 'etogo metoda v } \\
\text { lingvisticheskoj tipologii, a takzhe } \\
\text { interpretacii poluchenny rezul'tatov } \\
\text { (Rakhilina, Zevakhina, \& Dzhakupova, } \\
\text { 2013-). }\end{array}$ & $\begin{array}{l}\text { The conference focused mainly on } \\
\text { methodology issues [...] The conference } \\
\text { materials are a very valuable source for } \\
\text { analyzing, to what extent this method is } \\
\text { applicable in linguistic typology, as well as } \\
\text { for interpreting the results (translated by } \\
\text { Albina Vodaynitskaya and Vera } \\
\text { Yaremenko) }\end{array}$ \\
\hline
\end{tabular}

As we can see from the Table 2, the student emphasizes the value of the conference through the opportunities that it provides for a research. Implicitly, the possibility of a qualitative research is made (through mentioning interpreting). According to S.L. McGregor, it is the interpretation that makes a research qualitative (McGregor, 2018). The very naming the conference materials valuable inspires the reader of the review to give a closer look at the conference.

One more example from a student's thesis also falls into the category of research domain: here, the student focuses on linguistic data as a source:

Table 3 Linguistic data as a value (research domain)

\begin{tabular}{|l|l|}
\hline Transliterated version of the Russian text & \multicolumn{2}{|c|}{ Translation } \\
\hline massiv neslovarnyh slovoform yavlyaetsya & morphological forms that are not fixed in \\
istochnikom tsennogo lingvisticheskogo & dictionaries are a valuable source of \\
materiala, a imenno: novy slov i & linguistic data: new words and terminology, \\
terminologii, abbreviatur, nestandartnyh & abbreviations, non-standard forms of \\
form skloneniya i spryazheniya (Rakhilina, & conjugation and declension (translated by \\
Zevakhina, \& Dzhakupova, 2013-). & Albina Vodaynitskaya and Vera \\
& Yaremenko) \\
\hline
\end{tabular}

In this utterance from Table 3, through stating the value of a linguistic source, the student either invites the reader (a potential linguist) to research the linguistic material mentioned, or, what is more likely, justifies his choice of linguistic material for analysis.

When doing a research, students are involved in a breath-taking activity of searching for information, looking for solutions, structuring and arranging research findings. There are specific areas in the structure of a course paper or thesis, for example, which focus on the practical and theoretical values of the 
paper. In Russian academic discourse they are expressed by the words cennost' and tsenniy (value and valuable):

Table 4 A practical value of research results stated (research domain)

\begin{tabular}{|c|c|}
\hline Transliterated version of the Russian text & Translation \\
\hline $\begin{array}{l}\text { Rezul'taty dannogo issledovaniya } \\
\text { predstavlyayut prakticheskuyu tsennost } \\
\text { dlya vseh lyudej, } \text { kotorye planiruyut rabotat' } \\
\text { ili uzhe rabotayut v organizaciyah s } \\
\text { korporativnym dress-kodom (Rakhilina, } \\
\text { Zevakhina, \& Dzhakupova, 2013-). }\end{array}$ & $\begin{array}{l}\text { The research findings have a practical } \\
\text { value for all the people, planning to work, } \\
\text { or working in dress-code oriented } \\
\text { corporations (translated by Albina } \\
\text { Vodaynitskaya and Vera Yaremenko) }\end{array}$ \\
\hline
\end{tabular}

As it is shown in Table 4, the authors use the words valuable and value not in the sense that the first example implies, but differently: it is a standardized procedure to state the practical as well as the theoretical value of specific parts of the written text. The writer is 'inviting' the reader to appreciate the values of his or her practical and theoretical contribution.

\section{Values within the Educational Domain}

If the research domain is connected with searching for the solutions, looking for relevant scholarly information, creating a new text (course paper, thesis, dissertation etc.) and presenting it to academic society, educational domain contains examples which address the issues connected with learning various disciplines - not researching, but learning. A set of examples below, from (Nesi \& Thompson, 2000-) and (Michigan Corpus of Academic Spoken English, 2002-), illustrates teachers' perceptions of what is valuable in the educational process.

During the lecture on formal logic, the teacher is speaking about a rule and is describing it as valuable:

it's just an additional rule that will save you time and effort and it's a very valuable rule for that are there any questions about whole thing well when $i$ said there were various versions of this rule let 's ha just mention one to start with the rule of theorem introduction which is indeed (Nesi \& Thompson, 2000).

Rules as well as the parts of the books can be valuable for educational purposes:

... let's start out with the checklist, and if you notice how each chapter starts out with a little introduction and then right away there's a checklist, that's very valuablenot only for the reading but also for your assignments today, photographs that you brought in (Michigan Corpus of Academic Spoken English (2002-).) 
Here, the speaker (senior faculty, male, 51 years old and over) emphasizes the educational value of a checklist, for self-check is important in the educational process, because it also relates to self-assessment and feedback.

In the examples above teachers highlight the value of various disciplinespecific phenomena, while in the next one, the teacher enters a universal plain, emphasizing (during a lecture on biological sciences) the value and the universal nature of laboratory methods:

... if you intend to become a professional biologist evidently this laboratory course is extremely important to you even if you don't intend to become a professional biologist we all think that training in laboratory methods is very valuable to you in the sense of transferable skills because the skills of observing understanding and reporting are going to be useful to you in any profession whatever profession you choose be it biology or being a policeman so we think that these laboratory courses are extremely valuable and extremely important to you so you are now launched into your career as a professional biologist ... (Nesi \& Thompson, 2000).

In the first instance, the teacher explains, in what sense the laboratory methods are valuable: transferable skills that will be acquired by the students are named, evaluative lexis, emphasizing the value of the laboratory methods is relied upon: extremely important, extremely valuable. What is important, is that the teacher links the use of laboratory methods with students' professional careers and even demonstrates universal nature of the skills-to-be-acquired. Through the combination of linguistics (emphasizing adverb extremely, evaluative adjective important), didactics (naming of certain transferable skills) and sociological context (you are launched into your professional career as biologists) the teacher unveils the essence, the meaning of laboratory methods, showing their value and importance. Analyzing this vivid example, we see that for educational purposes, when the teacher labels something as valuable, he or she explains, on what grounds this or that phenomenon or discipline is considered valuable. All the educational roots are meant to bring students to their professional success, so teachers feel the incentive to disclose the value of each discipline for them - for the sake of motivation and academic success.

The research findings have revealed that it is possible to include into educational domain examples when students refer to education as a value: 
Table 5 Educational Domain

\begin{tabular}{|l|l|}
\hline Transliterated version of the Russian text & \multicolumn{1}{|c|}{ Translation } \\
\hline $\begin{array}{l}\text { Tsennost' gumanitarnogo obrazovaniya } \\
\text { otnyud' ne } v \text { tom, chto ono uchit stremit'sya }\end{array}$ & $\begin{array}{l}\text { The value of Humanities manifests itself not } \\
\text { in the fact that Humanities teach a person to } \\
k \text { celi, a } v \text { tom, chto chelovek yasno vidit } \\
\text { tsennost' } v \text { sovershenii samogo dejstviya } \\
\text { (Rakhilina, Zevakhina, \& Dzhakupova, } \\
\text { clearly sees the value in the action itself } \\
\text { (translated by Albina Vodyanitskaya and } \\
\text { Vera Yaremenko). }\end{array}$ \\
\hline
\end{tabular}

In this excerpt presented in Table 5 and retrieved from the paragraph, written by second-year student pursuing bachelor's degree in Design, the value of Humanities is in the focus of attention. The student does not merely states the value of Humanities, but reveals what aspect of the academic division is especially valuable for him.

\section{Values within the topic-related domain}

There is a scope of examples with the word valuable that does not directly corresponds to the academic values, but highlights the values relating to the broader topic of the colloquium, lecture, essay, or another institutional event or assignment. Teachers in there lectures and students in their essays attract their listeners' and readers' attention to phenomena they consider valuable:

[...] both what is valuable in humility and what is fruitful in the scientific temper.' Parenthetically, erm he says somewhere in his autobiography that the one thing that consoled him in the nineteen-hundreds when he was so miserable, was the devising of, was the devising of prose rhythms. (pause) And he did indeed, did he not, develop a beautiful ear. That was one sentence which I read, and it is perfect. (Davis, 2008-)

The teacher read out loud a passage, where the author states the value of humility. Further on, the teacher explains this passage with an example from the author's biography, when humility resulted in the devising of prose rhythms. The value of humility is highlighted by the fact that it lead to something lifeaffirming. It seems that through this example the teacher tries to show to his students that a person can find good even in humility, people tend to avoid unpleasant circumstances, but when they do come, creative work and belief in good outcomes, may help even create something meaningful for humanity. What seemed to be unbearable from the every-day life point of view, became a consolation and a cornerstone for the author's creative work.

The following example is from British National Corpus (Davis, 2008-), and what the teacher considers valuable here, is accompanied by an explanation containing evaluative lexis: 
... the rationale is that the degree of parental investment and its effect on the offspring vary with the offspring's age, and as (-----) says, one of the fundamental erm, principles of this is that, by and large the younger the offspring the more valuable any unit of parental is to it, and the more efficacious it is, and the most obvious example of that would be food. Obviously, if you're a very tiny newborn baby, the amount of food you need to er, put on extra pound weight, is, is not going to be the same as if you are a much larger child, and you want to put on proportionately the same amount of $X$ pounds, whatever it would be, it would be same (Davis, 2008-).

In the essay on children's psychological development the student (grade $\mathrm{M}$, level of studies - two), dwells on the factors that are valuable while socializing:

... There is little doubt however that factors such as attachment type and early experiences with reciprocal friendships are valuable in learning the necessary skills to socialise and which therefore give you an increased chance of being popular and having friends. It has been shown that lack of friends or being unpopular may lead to problems with psychological development and these seem to be more extreme with rejected rather... (Nesi, 2008-)

\section{Conclusions}

The research has revealed that corpus-based approach is a reliable one for revealing academic values. Teachers voice the values that are shared by the participants of academic discourse during the lectures and seminars.

Students voice the values they share and consider relevant when writing their research.

The values of academic discourse can be classified into emotional, cognitive, educational, research-related, academic life-related, topic- / arearelated.

Values connected to emotional domain are mostly interrelated with the experience of communicating with other members of academic discourse: teachers during the lectures remember with gratitude the academics that empowered them with their support, who trusted in them and helped them overcome various challenges.

Values within the cognitive domain are revealed in the contexts when teachers emphasize various aspects that are valuable from cognitive point of view: when, for example, they refer to the results of students' cognitive operations. Students' academic endeavor, their perseverance to achieve certain academic results is perceived as valuable by their teachers.

Values within the educational domain are related to books, rules, certain behavior patterns that are relevant in the educational process (for example, training to use laboratory methods is valuable for future biologists). 
Within research-related domain students (based on the analysis of the texts from the written corpora) dwell on practical, theoretical value, as well as on the value of dictionaries, approaches and other aspects connected with the research. It is relevant to mention that research-related values are mainly connected with the research ethics and the attitude with which the researcher approaches their research.

Values connected with academic life deal with behavioral patterns of teachers and students. Mutual respect, awareness of various rules governing academic institutionalized relationships, are considered to be valuable for academic life. Importantly, the analysis of corpora has revealed that students' feedback is valued by the academicians for it facilitates education process.

The question of topicality is relevant for academic discourse, for it is connected with research domain to the most extent. Therefore, when writing their papers, students emphasize that the topic they study is valuable. Teachers, for example, when lecturing, show that this or that topic under discussion is valuable in terms of ethics or in terms of applicability.

The findings have shown that the journey once undertaken into the world of academic values does not promise to be a short one. The research has revealed that the adjective valuable and tsenniy (valuable) often goes hand in hand with evaluative nouns and adjectives, thus specifying this or that aspect of the phenomenon that is considered valuable. The research gives certain insights on teaching English and Russian academic discourse: the corpora provide vast vistas of various academic values as well as genres, therefore, teaching the ethos of academic discourse as well as its established writing and speaking patterns.

Various corpora have made it possible to grasp a bulk of contexts that represent diverse values and to propose some suggestions for further research:

Firstly, it is possible to do a quantitative research to reveal institutional role- and institutional event-dependent values, for some corpora give detailed information about the type of event as well as about the roles of the participants.

Secondly, if we speak of linguistic applicability, the research can further be extended to the analysis of all the contexts containing the words synonymous to valuable (useful, helpful, important, rewarding etc.), for through these adjectives one can understand the values of the academe as well.

Thirdly, one can trace and compare values across disciplines as well as across spoken and written corpora.

By doing a cross-corpus validation (see, e.g., (Lijffijt \& Nevalainen, 2017), we have also shown that the research findings can be similar across corpora, which is, to some extent, can be explained by the fact that "both written and spoken genres are constituted by bundles of co-occurring features" (Bamford \& Bondi, 2005, p. XY). 
One more important aspect of the further research is the necessity to compare values voiced by scholars and by students.

To sum it all up, it's necessary to mention that all the studies devoted to various aspects of academic discourse are aimed at understanding the nature of this multi-layered institutionalized phenomena. And understanding between all the participants of academic discourse, as, stated in (Suleimanova, 2013), is one of the most important aspects in the academe.

\section{Acknowledgements}

Our special gratitude goes to Olga Arkadyevna Suleimanova, Doctor of Philology, Professor, Chairperson of the Department of Linguistics and Translation Studies in the Institute of Foreign Languages of Moscow City University for her ongoing support, care and guidance which are so valuable for us.

We are also thankful to the developers of English and Russian written academic corpora for the vistas of opportunities that their corpora offer to researchers.

\section{References}

Bakhtin, M. (1986). Speech Genres and other Late Essays, in M. Holquist (Ed.), Austin: University of Texas Press.

Bamford, J., \& Bondi, M. (2005). Dialogue within Discourse Communities. Metadiscursive Perspectives on Academic Genres, Ed. by J. Bamford and M. Bondi. Tuebingen: Max Niemeyer Verlag.

Carey, R. (2014). A closer look at laughter in academic talk: A reader response. Journal of English for Academic Purposes, 14, 118-123.

Channel, J. (2002). Corpus-based Analysis of Evaluative Lexis. In S. Hunston and G. Thompson (Eds.), Evaluation in Text: Authorial Stance and the Construction of Discourse, 56-73. Oxford: Oxford University Press.

Chia-Yen, L. (2012). Modifiers in BASE and MICASE: A Matter of Academic Cultures or Lecturing Styles? English for Specific Purposes, 31(2), 117-126.

Collister, L.B., \& Deliyannides, T.S. Principles for Success in the US Research Environment: Power Point Presentation. Pittsburg: University Library System, University of Pittsburgh. Retrieved from https://pitt.libguides.com/academicintegrity/researchethics

Fishman, T. (Ed.) (2014). The fundamental values of academic integrity. Clemson: Clemson University.

Giannoni, D.S. (2010). Mapping academic values in the disciplines: A corpus-based approach. Bern: Peter Lang.

Hartner-Tiefenthaler, M., Roetzer, K., Bottaro, G., \& Peschl, M.F. (2018). When relational and epistemological uncertainty act as driving forces in collaborative knowledge creation processes among university students. Thinking Skills and Creativity, 28, 21-40. 
Hsu, W. (2018). The most frequent BNC / COCA mid- and low-frequency word families in English-medium traditional Chinese medicine (TCM) textbooks. English for Specific Purposes, 51, 98-110.

Hyland, K. (2016). Teaching and Researching Writing, $3^{\text {rd }}$ edition. New York: Routledge.

Ivin, A.A. (2006). Aksiologiya. Moskva: Vysshaya shkola.

Jordan, M.E. (2015). Variation in students' propensities for managing uncertainty. Learning and Individual Differences, 38, 99-106.

Lijffijt, J., \& Nevalainen, T. (2017). A simple model for recognizing core genres in the British National Corpus. Retrieved from http://www.helsinki.fi/varieng/series/volumes/19/ lijffijt_nevalainen/

Masantiah, C., Pasiphol, S., \& Tangdhanakanond, K. Student and feedback: Which type of feedback is preferable? Kasetsart Journal of Social Sciences. Retrieved from https://doi.org/10.1016/j.kjss.2018.07.020

McGregor, S. L. T. (2018). Understanding and Evaluating Research: A Critical Guide. Thousand Oakes: Sage Publications.

Nesi H., \& Gardner, S. (2018). The BAWE corpus and genre families classification of assessed student writing. Assessing Writing, 38, 51-55.

Suleimanova, O.A. (2013). Linguistic Meta-Language as a Basis for Communication / Understanding: Abstract and Control. In Olga Suleimanova (Ed.), Understanding by Communication (pp. 70-79). Cambridge: Cambridge Scholars Publishing.

Robinson, S. (2009). Dialogue and Disputation: Towards an Ethics of Academic Discourse Susan Robinson. Proceedings of the 4th Asia Pacific Conference on Educational Integrity (4APCEI) 28-30 September 2009. University of Wollongong NSW Australia Refereed Paper.

Suleimanova, O.A. (2018). Akademicheskij diskurs kak nepreryvnyj dialog s Drugim, In Olga Suleimanova (Ed.), Diskurs kak universal'naya matrica verbal'nogo vzaimodejstviya (pp. 180-198). Moscow: LENAND.

Suleimanova, O.A., Yaremenko, V.I., \& Vodyanitskaya, A.A. (2018). Boosting Students' Self-esteem through Training them in Speaking Skills. ICERI 18 Proceedings, 10409-10413.

Vodyanitskaya, A.A. (2018). Verbal Evaluation as a Gateway to Inspire Life-long Learning in Students. Edulearn18 Proceedings, 5314-5318.

Zenobya, C.E., Chan, D., Meadus, R.J., \& Chien W. T. (2017). A qualitative study on feedback provided by students in nurse education. Nurse Education Today, 55, 128-133.

\section{Corpora cited}

Davis, M. (2008-). British National Corpus. Retrieved from https://corpus.byu.edu/bnc/

Michigan Corpus of Academic Spoken English (2002-). Retrieved from https://quod.lib.umich.edu/cgi/c/corpus/corpus?c=micase;page=simple

Nesi, H. (2008-). British Academic Written English. Retrieved from https://old.sketchengine.co.uk/corpus/first_form?corpname=preloaded/bawe2

Nesi, H., \& Thompson, P. (2000-). British Academic Spoken English. Retrieved from https://old.sketchengine.co.uk/corpus/first_form?corpname=preloaded/base

Rakhilina, E.V., Zevakhina, N.A., \& Dzhakupova, S.S. (2013-). Korpus Russkikh Uchebnykh Tekstov - Corpus of Russian Students Texts. Retrieved from https://ling.hse.ru/krut 